\title{
Roles for Riboflavin in the Sinorhizobium-Alfalfa Association
}

\author{
Guoping Yang, T. V. Bhuvaneswari, Cecillia M. Joseph, Maria D. King, and Donald A. Phillips \\ Department of Agronomy and Range Science, University of California, One Shields Avenue, Davis, CA 95616 U.S.A. \\ Submitted 24 September 2001. Accepted 25 January 2002.
}

\begin{abstract}
Genes contributing to riboflavin production in Sinorhizobium meliloti were identified, and bacterial strains that overproduce this vitamin were constructed to characterize how additional riboflavin affects interactions between alfalfa (Medicago sativa) and S. meliloti. Riboflavin-synthesis genes in $S$. meliloti were found in three separate linkage groups and designated as $\mathrm{ribBA}$, ribDribC, and $\mathrm{ribH}$ for their similarities to Escherichia coli genes. The ribBA and ribC loci complemented corresponding $E$. coli rib mutants. $S$. meliloti cells containing extra copies of ribBA released 10 to $20 \%$ more riboflavin than a control strain but grew at similar rates in a defined medium lacking riboflavin. Cells carrying extra copies of $r i b B A$ colonized roots to densities that were $55 \%$ higher than that of a control strain. No effect of extra rib genes was detected on alfalfa grown in the absence or presence of combined $N$. These results support the importance of extracellular riboflavin for alfalfa root colonization by $S$. meliloti and are consistent with the hypothesis that this molecule benefits bacteria indirectly through an effect on the plant.
\end{abstract}

Additional keywords: lumichrome, nitrogen fixation.

Riboflavin is a necessary component of the flavin coenzymes FMN and FAD in both bacteria and higher organisms (McCormick 1989). Less recognized is the fact that, although bacteria contain numerous flavoenzymes, synthesis of riboflavin can far exceed the amount required by those proteins. Thus, in Escherichia coli, the ratio of extracellular to intracellular metabolite is only 0.01 for amino acids and 0.05 for nucleic acid bases, but the corresponding value for riboflavin varies from 0.8 to 8.0 (Wilson and Pardee 1962). Riboflavin from $E$. coli cells presumably benefits human hosts, and the release of riboflavin by most root-colonizing bacteria (Strzelczyk and Rozycki 1985) suggests that this molecule may have evolved as a significant ecological factor in plantbacteria interactions.

Riboflavin clearly contributes to symbiotic associations between legumes and members of the family Rhizobiaceae. Rhizobia showing riboflavin auxotrophy form root nodules

Corresponding author: D. A. Phillips; Telephone: +1-530-752-1891; Fax: +1-530-752-4361; E-mail: daphillips@ucdavis.edu

Current address of G. Yang: MicroBio Rhizogen Corp., 3835 Thatcher Avenue, Saskatoon, SK S7R 1A3 Canada.

Current address of T. V. Bhuvaneswari: Department of Plant Physiology and Microbiology, University of Troms $\emptyset$, Troms $\emptyset$, Norway.

Nucleotide sequence data reported are available in the GenBank database under the accession numbers AF373806 and AF373807. but reduce little $\mathrm{N}_{2}$ (Schwinghamer 1970). Presumably, riboflavin present in root exudates (Rovira and Harris 1961) supports growth and root colonization by such auxotrophs, but riboflavin availability in the root zone can limit plantmicrobe interactions, because adding trace amounts of this vitamin to the rhizosphere increases alfalfa root colonization by Sinorhizobium meliloti 1021 (Sm1021) (Streit et al. 1996). The nature of that limitation is not clear because rhizobia, in general, do not respond with additional growth when riboflavin is supplied (Vincent 1977) and Sm1021, in particular, releases riboflavin in medium lacking riboflavin (Phillips et al. 1999). Some rhizobial riboflavin in the root zone is degraded to lumichrome, which stimulates root respiration (Phillips et al. 1999) and may, therefore, contribute to the exogenous $\mathrm{CO}_{2}$ required for growth by this organism (Lowe and Evans 1962). The question, therefore, is whether adding riboflavin to the rhizosphere promotes root colonization through direct effects on bacterial growth or through indirect promotion of bacterial growth, for example, by increasing root respiration or exudation. One approach to answering this question is to construct rhizobia that overproduce riboflavin. Unfortunately, no published information on riboflavin synthesis in the family Rhizobiaceae is available, and thus a series of preliminary studies was required.

Biochemical pathways for riboflavin synthesis and the rib genes required for those reactions are well characterized in both E. coli (Fig. 1) and Bacillus subtilis (Perkins and Pero 1993). Homologous genes have been identified by sequencing and/or complementation of defined $E$. coli mutants in Actinobacillus pleuropneumoniae (Fuller and Mulks 1995) and Haemophilus influenzae (Fleischmann et al. 1995). Riboflavin overproducers have been developed for pharmaceutical purposes (Demain 1972), and E. coli cells containing Helicobacter pylori ribBA excrete additional riboflavin (Worst et al. 1998), which facilitates iron acquisition and ferric-iron reduction in the transconjugants. This study was initiated to develop riboflavin-overproducing constructs of $S$. meliloti that could help clarify the role of riboflavin in $S$. meliloti-alfalfa interactions.

\section{RESULTS}

S. meliloti rib genes.

Using microbiological materials specified in Table 1, two separate $S$. meliloti genomic cosmids that complemented $E$. coli rib mutants were found. One restored growth in the absence of riboflavin to $E$. coli strains BSV18 and BSV11, which have mutations in $r i b A$ and $r i b B$, respectively, while another complemented E. coli strain BSV13, which is mutated in ribC. Restriction mapping, subcloning, and sequencing of the two cosmids established physical maps (Fig. 2A and B) and identi- 
fied open reading frames that code for amino acid sequences in $S$. meliloti that are 48 to $60 \%$ similar to corresponding E. coli and $H$. influenzae genes (Table 2). The corresponding complementation of E. coli strains BSV18 and BSV11 by the probable ribBA gene and of $E$. coli strain BSV13 by the putative ribC gene supports the conclusion that these $S$. meliloti genes are involved in riboflavin synthesis. The $62 \%$ homology of the $S$. meliloti RibBA protein to E. coli $\mathrm{RibB}$ at the $\mathrm{N}$-terminal end and the $48 \%$ homology to $E$. coli RibA at the C-terminal end (Table 2; Fig. 3 ) and the capacity of S. meliloti ribBA to complement both the ribA and ribB mutants of $E$. coli support the suggestion that $S$. meliloti produces a single, multifunctional RibBA protein, as occurs in Helicobacter pylori (Worst et al. 1998). The capacity of the complete ribBA sequence amplified by polymerase chain reaction (PCR) primers $G Y 50$ and $G Y 51$ to complement both the ribA and the $r i b B$ mutation in $E$. coli differs from the results obtained with ribBA in Helicobacter pylori, in which riboflavin synthesis was restored only in the ribB mutation in E. coli (Fassbinder et al. 2000). The presence in $S$. meliloti ribBA of two putative, in-frame translational stop sites, which are shown in Figure 3 as asterisks, was confirmed by sequencing three times and subsequently by $100 \%$ identity to data reported by the $S$. meliloti genome project (available online through Institut National de la Recherche Agronomique [INRA]).

Thus, the simplest conclusion is that $S$. meliloti ribBA produces a protein with the activities of both 3,4-dihydroxy-2butanone 4-phosphate synthase (Richter et al. 1992) and GTP cyclohydrolase (Richter et al. 1993), while $r i b C$ codes for riboflavin synthase (Eberhardt et al. 1996) (Fig. 1). Sequence analysis identified an open reading frame immediately upstream from ribC (Fig. 2B) with a predicted protein product similar to the RibD protein in E. coli (Taura et al. 1992) and $H$. influenzae (Fleischmann et al. 1995) (Table 2). The putative ribH gene amplified from $S$. meliloti genomic DNA (Fig. 2C), likewise, was identified by its $50 \%$ similarity to the amino acid sequence of the RibH proteins in E. coli (Taura et al. 1992) and H. influenzae (Fleischmann et al. 1995) (Table 2).

\section{Effects of extra rib genes on $\mathbf{S}$. meliloti.}

$S$. meliloti cells containing plasmid-borne copies of extra ribBA, Sm1021-GY1, consistently released 10 to $20 \%$ more ri- boflavin than the control strain Sm1021-WS12, which carries the empty plasmid vector (Fig. 4). Liquid cultures of Sm1021-GY1 could be visually separated from control cells by an obvious yellow color. In some tests, the presence of extra ribDribC genes, Sm1021-GY2, produced additional riboflavin (Fig. 4, day 3), but that result was not consistent (Fig. 4, day 4). Sm1021-GY4 containing extra ribH genes produced no additional riboflavin during initial pure-culture tests and was not examined further for this capacity. Highperformance liquid chromatography (HPLC) analyses of riboflavin and lumichrome released from bacteria incubated 3 days in a $\mathrm{C}$ - and $\mathrm{N}$-deficient "root-exudate" medium showed similar increases in total flavins (mean \pm standard error $[\mathrm{SE}], \mathrm{nmol} / \mathrm{ml}$ ) associated with extra copies of ribBA: Sm1021, $4.07 \pm 0.08$; Sm1021-GY5, 5.08 \pm 0.72; and Sm1021-TVB1, $5.00 \pm 1.34$.

Cells containing extra ribBA genes showed highly significant increases in $\mathrm{N}$ content when grown in Vincent's defined medium (Table 3), and the liquid supernatant was visibly yellow in comparisons with control strains. In tests with both Vincent's defined medium lacking riboflavin (Fig. 4) and the "root-exudate" medium (data not shown), extra rib genes had no effect on cell growth, measured either by 600-nm absorbance or by direct counts of CFU. Thus, there was no evidence to support the concept that $S$. meliloti strains with a normal complement of rib genes examined in this study were deficient in the riboflavin production required for growth in pure culture.

The most striking result of this study was that a strain containing extra copies of ribBA, which produced slightly elevated levels of riboflavin, colonized alfalfa roots to a much greater extent than the control (Fig. 5), even though the strain exhibited no corresponding increase in growth in pure culture (Fig. 4). In a representative experiment, the presence of extra ribBA (Sm1021-GY1) increased root colonization by 55\% (Fig. 5). Sm1021-GY2 containing extra copies of ribDribC never colonized roots better than the control strain, despite an occasional transitory increase in riboflavin production (Fig. 4). This colonization test was a direct measure of cell growth in the root zone, because after 6 days, 40,000 to 60,000 CFU were recovered on the root from an inoculum of $400 \pm 70$ cells (mean \pm
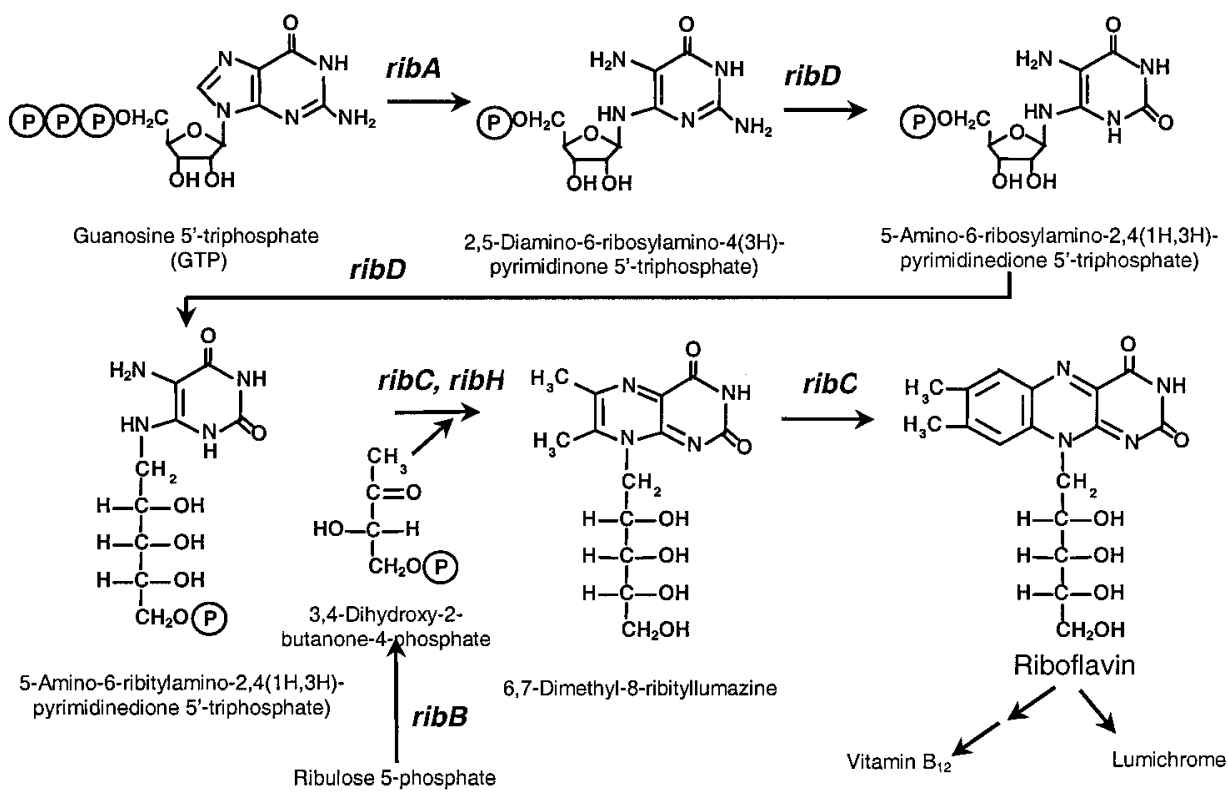

Fig. 1. Riboflavin biosynthesis and the Escherichia coli genes involved, based on Richter and colleagues (1992, 1997). 
$\mathrm{SE}$ ). The plasmid pLAFR3 was maintained stably in these tests, as reported previously (Streit and Phillips 1996).

\section{Plant experiments.}

Symbiosis tests showed no effects of extra ribBA genes in Sm1021 on either plant growth or $\mathrm{N}_{2}$ fixation. In 5-week plantgrowth experiments using Sm1021-GY1, Sm1021-GY5, or Sm1021-TVB1 with Sm1021-WS12 or Sm1021 as the appropriate control strain, bacterial genotypes had no significant effect on plant dry weight in the presence or absence of mineral $\mathrm{N}$ (data not shown).

Experiments designed to test whether extra riboflavin production by rhizosphere bacteria could promote bacterial growth on roots by increasing exudation of amino acids also gave negative results. In those experiments, 20 or $200 \mathrm{nM}$ riboflavin was supplied to roots of sterile, hydroponically grown alfalfa seedlings for 5 days, and picomolar amounts of amino acids in the root solution were separated by HPLC and quantified with a fluorescence assay on day 0 and day 5. No significant increase in any amino acid in the exudates was detected with either riboflavin treatment (data not shown).

\section{DISCUSSION}

Results from this study establish that S. meliloti genes involved in riboflavin synthesis are functionally and structurally

Table 1. Strains and plasmids used in this study

\begin{tabular}{|c|c|c|}
\hline Strain & Relevant traits $^{\mathrm{z}}$ & Source or reference \\
\hline \multicolumn{3}{|l|}{ Escherichia coli } \\
\hline DH5 $\alpha$ & recA1, $\Delta l a c Z$ & Invitrogen, Carlsbad, CA, U.S.A. \\
\hline HB101 & pRK2013 helper strain for matings & Stratagene, La Jolla, CA, U.S.A. \\
\hline S17-1 & Modified RP4 integrated into genome & Simon et al. (1983) \\
\hline BSV18 & ribA:Tn5 mutant, $\mathrm{Km}^{\mathrm{r}}$ & Bandrin et al. (1983) \\
\hline BSV11 & $r i b B: \operatorname{Tn} 5$ mutant, $\mathrm{Km}^{\mathrm{r}}$ & Bandrin et al. (1983) \\
\hline BSV13 & ribC:Tn5 mutant, $\mathrm{Km}^{\mathrm{r}}$ & Bandrin et al. (1983) \\
\hline \multicolumn{3}{|c|}{ Sinorhizobium meliloti } \\
\hline Sm1021 & $\mathrm{Sm} 2011, \mathrm{Sm}^{\mathrm{r}}$ & Meade et al. (1982) \\
\hline Sm102F51 & Field isolate & Nitragin Co., Milwaukee, WI, U.S.A. \\
\hline Sm1021-WS12 & Sm1021pLAFR3 & Streit and Phillips (1996) \\
\hline Sm1021-GY1 & Sm1021pLAFR 3 containing Sm1021 ribBA & This work \\
\hline Sm1021-GY2 & Sm1021pLAFR3 containing Sm1021 ribDribC & This work \\
\hline Sm1021-GY4 & Sm1021pLAFR3 containing Sm1021 ribH & This work \\
\hline Sm1021-GY5 & Sm1021pSUP205ribBA recombinant, fast growth on $5 \mu \mathrm{g}$ of Tc per ml & This work \\
\hline Sm102F51-GY6 & Sm102F51pSUP205ribBA recombinant, fast growth on $5 \mu \mathrm{g}$ of Tc per ml & This work \\
\hline Sm1021-TVB1 & Sm1021pSUP205ribBA recombinant, slow growth on $2.5 \mu \mathrm{g}$ of Tc per ml & This work \\
\hline \multicolumn{3}{|c|}{ Plasmids/transposons } \\
\hline pBSK+ & Multicopy cloning vector, $\mathrm{Ap}^{\mathrm{r}}$ & Stratagene, La Jolla, CA, U.S.A. \\
\hline pCR2.1 & Multicopy cloning vector, $\mathrm{Ap}^{\mathrm{r}}, \mathrm{Km}^{\mathrm{r}}$ & Invitrogen, Carlsbad, CA, U.S.A. \\
\hline pLAFR3 & pLAFR 1 derivative, $m o b, \lambda \cos , \mathrm{Tc}^{\mathrm{r}}$, low copy in both $E$. coli and $S$. meliloti & Staskawicz et al. (1987) \\
\hline pJQ200mp18 & $\mathrm{pACYC} 184 o r i, m o b, s a c B, \mathrm{Gm}^{\mathrm{r}}$ & Quandt and Hynes (1993) \\
\hline pRK2013 & pRK212.2 conjugation helper plasmid & Figurski and Helinski (1979) \\
\hline pSUP205 & $\begin{array}{l}\text { pBR325 derivative, } m o b, \lambda \cos , \mathrm{Cm}^{\mathrm{r}}, \mathrm{Tc}^{\mathrm{r}} \text {, multicopy in } E \text {. coli, does not replicate } \\
\text { in } S \text {. meliloti }\end{array}$ & Simon et al. (1983) \\
\hline$\Omega-\mathrm{Tc}$ & pUT::mini-Tn5Tc, $\mathrm{Tc}^{\mathrm{r}}$ & De Lornezo et al. (1990) \\
\hline
\end{tabular}

${ }^{\mathrm{z}} \mathrm{Ap}=$ ampicillin, $\mathrm{Cm}=$ chloramphenicol, $\mathrm{Gm}=$ gentamicin, $\mathrm{Km}=$ kanamycin, $\mathrm{Sm}=$ streptomycin, and $\mathrm{Tc}=$ tetracycline.
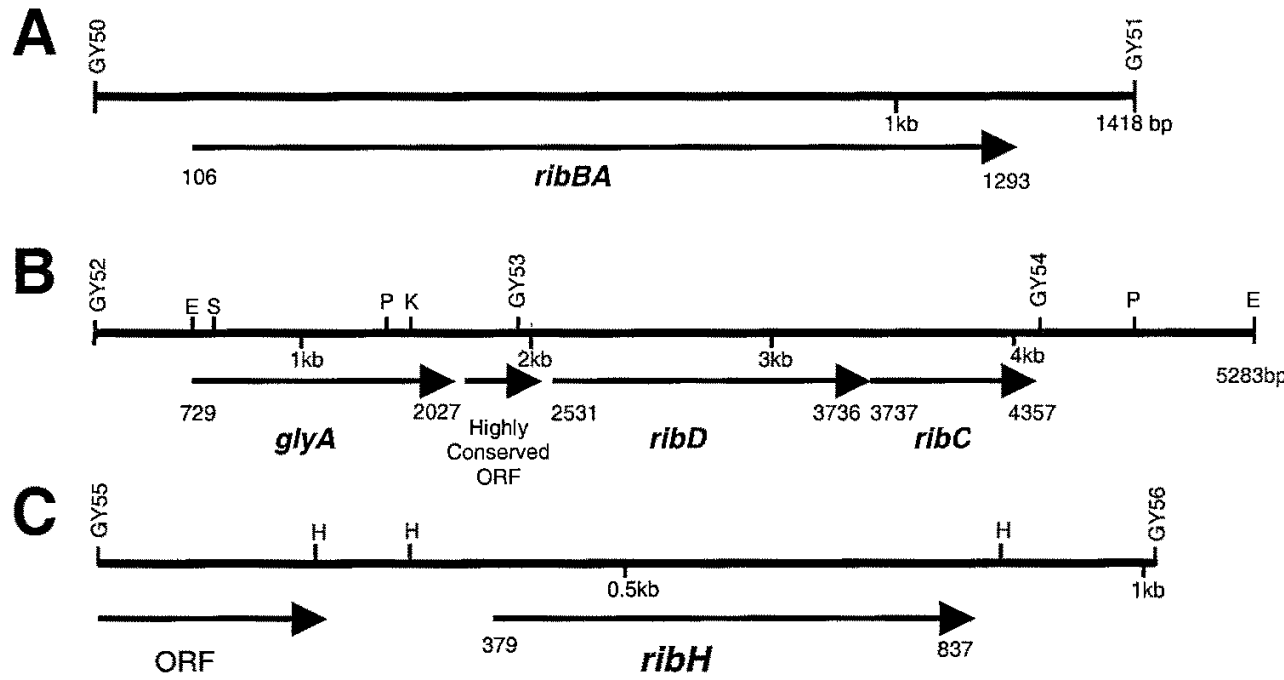

Fig. 2. Riboflavin biosynthesis genes from Sinorhizobium meliloti. A, ribBA; B, ribDribC; and $\mathbf{C}$, ribH. Restriction sites are represented as E, EcoRI; H, HindIII; K, KpnI; P, PstI; and S, SmaI. Arrows below the map indicate open reading frames predicted from nucleotide sequence analysis. Polymerase chain reaction primers denoted by GY50 to GY56 are specified in text. 
related to $E$. coli homologues and that increased riboflavin production enhances alfalfa root colonization. Although a role for riboflavin in symbiotic performance of rhizobia was indicated previously by comparing auxotrophic and prototrophic strains (Schwinghamer 1970), our data show that a small increase (10 to $20 \%$ ) in the capacity to release riboflavin in S. meliloti (Fig. 4) enhances root colonization (Fig. 5) without altering symbiotic performance. The importance of riboflavin production for root colonization was first suggested by the ecological observation that bacteria isolated from pine roots (Pinus sylvestris L.) produced fivefold more riboflavin in pure culture than those obtained from nearby root-free soil (Strzelczyk and Rozycki 1985). Physiological evidence for flavin limitations in the rhizosphere came from the observa-

Table 2. Similarity in amino acid sequences of riboflavin-synthesis proteins

\begin{tabular}{|c|c|c|c|c|c|c|c|c|}
\hline \multirow[b]{3}{*}{ Bacterium } & \multicolumn{8}{|c|}{ \% Similarity of Sinorhizobium meliloti ${ }^{\mathrm{x}}$} \\
\hline & \multicolumn{2}{|c|}{ RibBA } & \multicolumn{2}{|l|}{ RibC } & \multicolumn{2}{|l|}{ RibD } & \multicolumn{2}{|l|}{ RibH } \\
\hline & Compared with & $\%$ & Compared with & $\%$ & Compared with & $\%$ & Compared with & $\%$ \\
\hline Escherichia coli & $\begin{array}{l}\text { RibA } \\
\text { RibB }\end{array}$ & $\begin{array}{l}48^{y} \\
62^{z}\end{array}$ & RibC & 55 & RibD & 59 & RibH & 50 \\
\hline Haemophilus influenzae & $\begin{array}{l}\text { RibA } \\
\text { RibB }\end{array}$ & $\begin{array}{l}51^{y} \\
65^{\mathrm{z}}\end{array}$ & RibC & 56 & RibD & 52 & $\mathrm{RibH}$ & 50 \\
\hline
\end{tabular}

${ }^{\mathrm{x}}$ Similarity is expressed as conserved residues calculated by GenBank analysis (Altschul et al. 1990) using sequences reported for $E$. coli RibA (Richter et al. 1993), RibB (Richter et al. 1992), RibC (Eberhardt et al. 1996), RibD (Taura et al. 1992), and RibH (Taura et al. 1992) or for H. influenzae (Fleischmann et al. 1995).

y Sequence similarity to (C terminal) 188 amino acids of $S$. meliloti RibBA.

${ }^{\mathrm{z}}$ Sequence similarity to (N terminal) 208 amino acids of $S$. meliloti RibBA.
S. meliloti
E. $\operatorname{coli}$
E. $\operatorname{coli}$
RibA:
RibB :
MSYDQRRVVEATRAFEAGEIVVVVTDDGGRENEGDIIVAAVHCTPETMAFI ll I I I I I II IIIIII I I I I II ERVENALAALREGRGVMIVLDDEDRENEGDMIFPAETMTVEQMALT

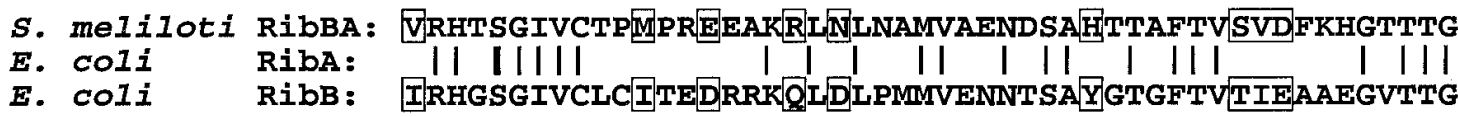

S. meliloti RibBA: ISADDRTLTVRNLANPNVGPTDFVRPGHIFPLVAREGGVLMRGHTEAAV

E. coli

E. $\operatorname{coli}$

RibA:

RibB :

II II III

VSAADRITTVRAAIADGAKPSDLNRPGHVFPLRA_AGGVLTRGGHTEATI

s. meliloti

E. $\operatorname{coli}$

E. $\operatorname{coli}$

RibBA :

RibA:

DLCRLASLPPIGVICELVNDDGTVMRGPQVEAFAETHGLKQVISVADLIAY

RibB : DLMTLAGFKPAGVICELTNDDGTMARAPECIEFANKHNMALVTIEDIVAY

S. meliloti RibBA: RQRKETLIEQGHSFEMDTPYGKAKGHTYSLPWDTMQHUAVVFGDIRDGVD

E. coli RibA: || |

E. COIi RIbB: RQAHE

$1 \mid 111$

HVA:LVYGDISGHTP

\title{
S. meliloti RibBA: IPVRIHLENVGADVFGRGRQIDEIMTKIAAEGRGVIVYLREGSVGVGISQ E. cOli RibA: VLARVHSECITGDALFSGF OLEAAITQIAEEGRGILLYHRQEGRNIGLLN Insertions in RibA:
}

\begin{abstract}
S. meliloti RibBA: TARKGKH国REVATSAOERESEWL国IGLGAHILKDLGITSIRLLSSRERHY E. COIi RibA KIRAYALQDQGGDTVEANHADERDFTLCADMFKLLGVNEVRLL TNNPQ Insertions in RibA:
\end{abstract}

\section{s. meliloti RibBA: VGLEGFGIKIAATEIL*IRKSPK* 国PRHPTRLPRLEASCRYGRAS* E. CO1i RIBA: EILTEAGINIVERVPLIVGRNPNNEHYLDTEAEKM}

Fig. 3. Comparison of the Sinorhizobium meliloti strain Sm1021 RibBA (395 amino acids) with the RibA and RibB homologues in Escherichia coli. Identical amino acids in the homologues are linked by lines; comparable amino acids are enclosed with borders. Asterisks (*) indicate apparent stop codons. 
tion that adding nanomolar amounts of riboflavin to the alfalfa rhizosphere increased $S$. meliloti root colonization (Streit et al. 1996). Data reported here offer the first genetic evidence for a link between riboflavin production and root colonization (Fig. 5) and show that riboflavin effects in the rhizosphere are not simply explained by a direct effect on growth of the bacterial cells producing it. Our interpretation of the evidence, which is discussed below, suggests that beneficial effects of extracellular riboflavin on rhizosphere bacteria probably are mediated by the plant.

The amounts of riboflavin overproduction measured in this study were small compared with those observed in microorganisms modified for the pharmaceutical synthesis of this vitamin (Demain 1972). For this reason, the overproducing strains described here can be viewed as practical tools for testing ecologically relevant hypotheses. Strains characterized in Table 3 might be used, for example, to test the effects of riboflavin production on predation by nematodes.

The mechanism or mechanisms by which our strains produce additional riboflavin probably involve an increased conversion of GTP at the beginning of the pathway (Fig. 1). This suggestion is based on the fact that the RibA and RibB proteins in E. coli, for which Sm1021 ribBA substituted in the complementation tests, interact with GTP at the first committed step toward riboflavin biosynthesis. Extra copies of ribBA clearly increased riboflavin production (Fig. 4), and this fact suggests that, in Sm1021, the reaction of RibBA with GTP normally limits riboflavin synthesis.

The exact mechanism by which riboflavin contributes to root colonization by $S$. meliloti remains to be clarified. The simple explanation would be that extracellular riboflavin, either added to the rhizosphere by the investigator (Streit et al. 1996) or supplied through genetic modification of the bacteria (Fig. 5), increases root colonization by direct effects on bacterial cells that are deficient in the vitamin. This explanation, however, is not consistent with several facts. First, Sm1021 is not a riboflavin auxotroph because, even without extra rib genes, it grows and releases riboflavin into a medium lacking riboflavin (Phillips et al. 1999) (Fig. 4). Second, there is no evidence that Sm1021 cells are physiologically deficient in riboflavin under

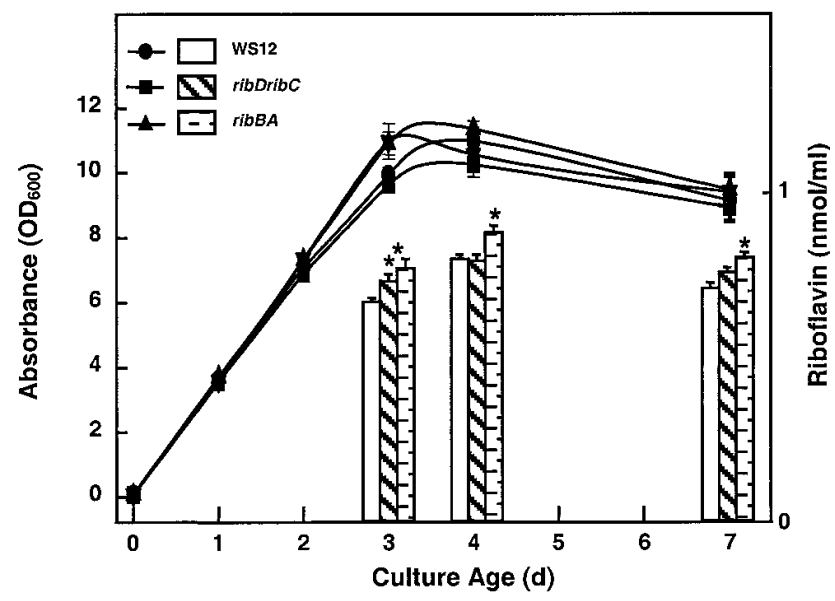

Fig. 4. Growth and riboflavin production in Vincent's defined medium lacking riboflavin by recombinant Sinorhizobium meliloti strains containing extra copies of riboflavin biosynthesis genes in pLAFR3. Sm1021GY1 and Sm1021-GY2 were constructed with the self-replicating plasmid pLAFR3; the control strain Sm1021-WS12 contained an empty pLAFR3. Mean cell numbers ( \pm standard error) did not differ significantly among genotypes on days 3 and 4 , when they were $1.18 \times 10^{9} \pm 1.52 \times 10^{7}$ and $1.22 \times 10^{9} \pm 5.76 \times 10^{6}$, respectively. Gene effects were significant at $P \leq$ $0.05(*)$. any growing conditions tested here, because extra copies of the ribBA gene had no effect on growth in pure culture, even though the bacterial population was exposed to higher levels of riboflavin (Fig. 4). (One can note in passing that extracellular riboflavin is not used easily by all bacteria. E. coli riboflavin auxotrophs studied here, for example, grew only when riboflavin was supplied at levels that created a visibly yellow medium.) Rhizobial cells containing extra copies of ribBA genes clearly had higher $\mathrm{N}$ contents (Table 3 ), but the only physiological effect associated with that additional internal $\mathrm{N}$ in these studies was an increase in root colonization (Fig. 5). This analysis suggests that one can look outside the bacterial cell to understand how riboflavin is functioning in this plant-bacteria interaction. One possibility is that riboflavin produced by bacteria increases their growth on roots indirectly through an effect on the plant.

Rhizosphere bacteria benefit greatly from carbon supplied by the root, including both reduced-carbon compounds and, possibly, $\mathrm{CO}_{2}$. In the case of rhizobia, exogenous $\mathrm{CO}_{2}$, which they require for growth (Lowe and Evans 1962), may come partially from the increase in root respiration that occurs in the presence of lumichrome, a degradation product of riboflavin (Phillips et al. 1999). Results from the current study are consistent with that mechanism, if extra riboflavin from the ribBA transconjugants was degraded to lumichrome and increased root respiration. Unfortunately, such parameters cannot be measured without disturbing a root-colonization test. It is also possible that bacterial riboflavin can affect net exudation of reduced-carbon compounds from the root. We found no evidence for such an effect on amino acids, but a new, highly sensitive fluorescence assay for carbohydrates (Honda et al. 2000) should permit more detailed analyses in the future.

\section{MATERIALS AND METHODS}

\section{Bacterial strains, media, and chemicals.}

Strains and plasmids used in this study are listed in Table 1. $\mathrm{Sm} 1021$ and its derivatives were grown at $28^{\circ} \mathrm{C}$ in complex TY (Beringer 1974); in Vincent's defined minimal, riboflavin-free medium (Vincent 1970) containing glucose $(10 \mathrm{mg} / \mathrm{ml})$; or in alfalfa (Medicago sativa L.) "root exudate," which is described under plant tests.

E. coli was grown at $37^{\circ} \mathrm{C}$ in Luria-Bertani (LB) medium (Sambrook et al. 1989). Antibiotics, unless otherwise stated, were used at the following concentrations: kanamycin, $25 \mu \mathrm{g} / \mathrm{ml}$ for $E$. coli, $200 \mu \mathrm{g} / \mathrm{ml}$ for $S$. meliloti; chloramphenicol, $50 \mu \mathrm{g} / \mathrm{ml}$; tetracycline, $5 \mu \mathrm{g} / \mathrm{ml}$ for $S$. meliloti, $10 \mu \mathrm{g} / \mathrm{ml}$ for $E$. coli; ampicillin, $50 \mu \mathrm{g} / \mathrm{ml}$; and streptomycin, $400 \mu \mathrm{g} / \mathrm{ml}$. E. coli mutants ribA:Tn5 (BSV18), ribB:Tn5 (BSV11), and ribC:Tn5 (BSV13) (Bandrin et al. 1983), which were generously supplied by B. Bachmann from the E. coli Genetic Stock Center, Yale University, New Haven, CT, U.S.A., were maintained on a high-riboflavin medium $\left(\mathrm{K}_{2} \mathrm{HPO}_{4}, 2 \mathrm{mg} / \mathrm{ml} ; \mathrm{KH}_{2} \mathrm{PO}_{4}, 1 \mathrm{mg} / \mathrm{ml}\right.$; $\mathrm{NH}_{4} \mathrm{Cl}, 2.5 \mathrm{mg} / \mathrm{ml} ; \mathrm{MgSO}_{4}, 250 \mu \mathrm{g} / \mathrm{ml}$; glucose, $10 \mathrm{mg} / \mathrm{ml}$; casein hydrolysate, $10 \mathrm{mg} / \mathrm{ml}$; and riboflavin, $2.5 \mu \mathrm{g} / \mathrm{ml})$. Stan-

Table 3. Effects of extra ribBA genes on $\mathrm{C}$ and $\mathrm{N}$ content of Sinorhizobium meliloti grown to stationary phase in Vincent's defined medium lacking riboflavin ${ }^{\mathrm{z}}$

\begin{tabular}{lcccr}
\hline Strain & Extra genes & C \% & N \% & C/N \\
\hline Sm1021 & None & $47.6 \mathrm{a}$ & $4.59 \mathrm{a}$ & $10.4 \mathrm{a}$ \\
Sm1021-GY5 & ribBA & $38.9 \mathrm{~b}$ & $8.43 \mathrm{c}$ & $4.6 \mathrm{~b}$ \\
Sm102F51 & None & $41.3 \mathrm{~b}$ & $6.96 \mathrm{~b}$ & $5.9 \mathrm{~b}$ \\
Sm102F51-GY6 & ribBA & $40.6 \mathrm{~b}$ & $8.47 \mathrm{c}$ & $4.8 \mathrm{~b}$ \\
\hline
\end{tabular}

${ }^{\mathrm{z}}$ Mean values in a column followed by different letters $(\mathrm{a}, \mathrm{b}, \mathrm{c})$ show significant $(P \leq 0.05)$ genotype effects. 
dard chemicals, reagents, and antibiotics were purchased from Fisher Scientific (Santa Clara, CA, U.S.A.) and Sigma Chemical Co. (St. Louis, MO, U.S.A.).

\section{Isolation of $\boldsymbol{S}$. meliloti genes.}

Three major rib genes were located in Sm1021 by complementing defined E. coli mutants. Genomic Sm1021 DNA was partially digested with Sau3AI, and the 5- to 8-kilobase fragments were collected after electrophoresis in $0.8 \%$ agarose gels. Those DNA fragments were ligated into $\mathrm{pBSK}+$ and electroporated into the $E$. coli rib mutants. Cells were allowed to recover in SOC medium (Sambrook et al. 1989) with riboflavin $(2.5 \mu \mathrm{g} / \mathrm{ml})$ for $5 \mathrm{~h}$ at $37^{\circ} \mathrm{C}$, and then riboflavin-synthesizing transformants were selected by several passages on LB medium containing kanamycin and ampicillin. Plasmids complementing the rib mutants were isolated for further study. The unannotated nucleotide sequence for the Sm1021 genome, which became available during the final stages of this work ( $S$. meliloti genome project [available online through INRA]), was searched for homologies to $E$. coli ribH (Taura et al. 1992), and a putative ribH gene was amplified by PCR from genomic Sm1021 DNA using primers GY55, 5'-ATG CCG ATA TCC TTG AGA CCG-3', and GY56, 5'-GTC TGC CCG GAG ATA GGT GTC-3'. The resulting product (Fig. 2C) was ligated into pLAFR3.

$S$. meliloti DNA complementing the E. coli ribA, ribB, and $r i b C$ mutants was subcloned into pCR2.1 with a TOPO TA Cloning Kit (Invitrogen, Carlsbad, CA, U.S.A.), and both strands of the complementing DNA were sequenced automatically (ABI 377; Applied Biosystems Perkin-Elmer, Foster City, CA, U.S.A.) at the Division of Biological Sciences DNA Sequencing Facility (University of California, Davis, U.S.A.) using primers specified by the manufacturer. Assembled sequences were analyzed for similarities to known sequences using the BLAST tool (Altschul et al. 1990).

\section{Construction of riboflavin-overproducing strains.}

To construct Sm1021 strains containing extra rib genes, DNA was amplified by PCR using the following primers (Fig. 2): $G Y 50,5^{\prime}$-GGC GGC TGA AGT AAC TCC ACT-3'; GY51, 5'-AAG ACG AGC TTC TCA AGA CCT-3'; GY52, 5'-CCG AAG AGG TCC CGG TCT ACT-3'; GY53, 5'-GTC TTC GGA ACC GCA ATA GGG-3'; GY54, 5'-GAC GTT ATT CCT GCT TGG GAG-3'; and GY55 and GY56 specified above. The ends of these DNA fragments were modified as required and inserted into the multiple-cloning sites of pLAFR3 and pSUP205. Sm1021-GY5, Sm102F51-GY6, and Sm1021-TVB1 were constructed by mating the nonreplicating vector pSUP205 with ribBA into either Sm1021 or Sm102F51. This technique produces an integration by recombination into the ribBA region of the chromosome, and selection on tetracycline gives rise to a nontandem direct duplication of ribBA and the associated vector (Mavingui et al. 1997). Sm1021-TVB1 and Sm1021-GY5 were selected for growth on 2.5 and $5 \mu \mathrm{g}$ of tetracycline per $\mathrm{ml}$, respectively, to yield strains with different copy numbers of ribBA. Sm102F51-GY6 was selected on $5 \mu \mathrm{g}$ of tetracycline per $\mathrm{ml}$.

\section{Riboflavin production tests.}

Tests for riboflavin production (i.e., synthesis and release) in pure culture were conducted with bacteria growing in Vincent's minimal medium. Bacteria were removed by centrifugation, and absorbance at $444 \mathrm{~nm}$ was measured in a Perkin-Elmer Lambda 20 spectrophotometer using fresh medium as a control and standard curves determined from known concentrations of authentic riboflavin.

\section{Plant tests.}

Alfalfa seedlings used for producing hydroponic root exudates were generated by a procedure verified to give sterile plants when tested on TY medium. This method involves treating unscarified seeds $(500 \mathrm{mg}) 8 \mathrm{~min}$ with concentrated $\mathrm{H}_{2} \mathrm{SO}_{4}$, rinsing with six volumes of sterile water, and then soaking for 25 to $30 \mathrm{~min}$ in commercial bleach solution $(5.25 \% \mathrm{NaClO}$, $\mathrm{wt} / \mathrm{vol}$ ) and rinsing again with six volumes of sterile water. Finally, the seeds are soaked overnight at $4{ }^{\circ} \mathrm{C}$ in a solution containing ampicillin $(100 \mu \mathrm{g} / \mathrm{ml})$, kanamycin $(100 \mu \mathrm{g} / \mathrm{ml})$, and rifampicin $(10 \mu \mathrm{g} / \mathrm{ml})$. Seeds treated with these procedures were rinsed extensively with sterile water before being placed in a sterile hydroponic chamber consisting of a petri dish $(90 \times$ $25 \mathrm{~mm}$, diameter $\times$ height) containing $25 \mathrm{ml}$ of sterile $\mathrm{N}$-free mineral solution (Fåhraeus 1957) with a cheesecloth seed bed supported by wire mesh. The 130 resulting seedlings were grown without aeration for 5 days before collecting the rootexudate-containing solution. Sterility of the solution from every container was verified on TY medium before it was stored at $-20^{\circ} \mathrm{C}$. Seedlings also were verified for external sterility of roots by streaking on TY.

Assays for bacterial colonization of alfalfa cv. Moapa 69 roots were performed in vermiculite as described previously (Streit et al. 1996). In these tests, the roots of sterile, 24-hold seedlings were inoculated with small numbers of cells (250 to 550 CFU per plant), and bacterial growth was assessed by isolating cells from roots after 6 days. In cases in which symbiotic properties of bacteria were assessed, larger numbers of cells (e.g., $10^{8} \mathrm{CFU}$ per plant) were inoculated onto roots of sterile, 24-h-old seedlings growing in vermiculite Leonard jars containing $\mathrm{N}$-free nutrient solution (DeJong and Phillips 1981). Plants were harvested after 28 to 35 days to record fresh weight and dry weight of shoots and roots.

\section{Chemical analyses.}

Amino acids were separated by HPLC and quantified with a fluorescent tag (Cohen and Michaud 1993) using the AccQ Tag system (Waters, Milford, MA, U.S.A.) according to the manufacturer's protocol. Total $\mathrm{C}$ and $\mathrm{N}$ content were analyzed by combustion (Pella 1990a, 1990b).

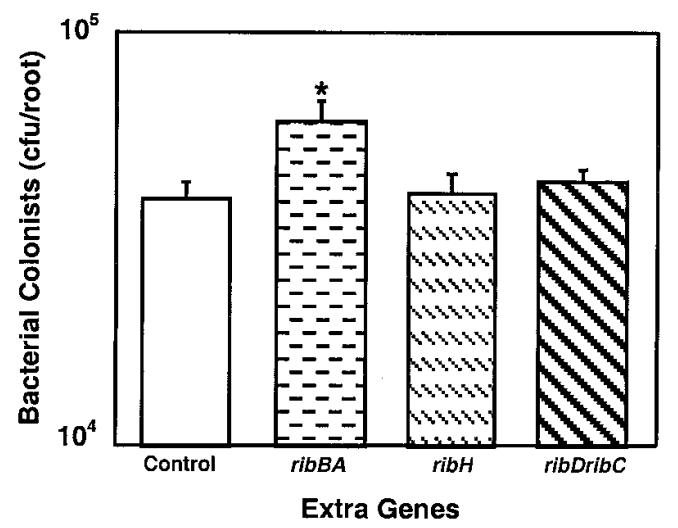

Fig. 5. Alfalfa root colonization by recombinant Sinorhizobium meliloti strains containing extra copies of riboflavin biosynthesis genes. Sm1021GY1, Sm1021-GY2, and Sm1021-GY4 were constructed with the selfreplicating plasmid pLAFR3; the control strain Sm1021-WS12 contained an empty pLAFR3. The effect of $r i b B A$ on root colonization $(+55 \%)$ was significant at $P \leq 0.05(*)$, as shown on the log scale. Error bars indicate 1 standard error (SE). An average ( \pm SE) of $400 \pm 70$ cells was inoculated on each root 6 days before colonization was measured. 


\section{ACKNOWLEDGMENTS}

This work was supported by U.S. National Science Foundation grants IBN-9722988 and DEB-0120169.

\section{LITERATURE CITED}

Altschul, S. F., Gish, W., Miller, W., Myers, E. W., and Lipman, D. J. 1990. Basic local alignment search tool. J. Mol. Biol. 215:403-410.

Bandrin, S. V., Rabinovich, P. M., and Stepanov, A. I. 1983. Three linkage groups of the genes of riboflavin biosynthesis in Escherichia coli. Genetika 19:1419-1425.

Beringer, J. E. 1974. R factor transfer in Rhizobium leguminosarum. J. Gen. Microbiol. 84:188-198.

Cohen, S. A., and Michaud, D. P. 1993. Synthesis of a fluorescent derivatizing reagent, 6-aminoquinolyl- $N$-hydroxysuccinimidyl carbamate, and its application for the analysis of hydrolysate amino acids via high-performance liquid chromatography. Anal. Biochem. 211:279-287.

DeJong, T. M., and Phillips, D. A. 1981. Nitrogen stress and apparent photosynthesis in symbiotically grown Pisum sativum L. Plant Physiol. 68:309-313

De Lornezo, V., Herrero, M., Jakubzik, U., and Timms, K. N. 1990. MiniTn5 transposon derivatives for insertion mutagenesis, promoter probing, and chromosomal insertion of cloned DNA in gram-negative eubacteria. J. Bacteriol. 172:6568-6572.

Demain, A. L. 1972. Riboflavin oversynthesis. Annu. Rev. Microbiol. 26: 369-388.

Eberhardt, S., Richter, G., Gimbel, W., Werner, T., and Bacher, A. 1996. Cloning, sequencing, mapping and hyperexpression of the ribC gene coding for riboflavin synthase of Escherichia coli. Eur. J. Biochem. 242:712-719.

Fåhraeus, G. 1957. The infection of clover root hairs by nodule bacteria, studied by a simple glass slide technique. J. Gen. Microbiol. 16:374381 .

Fassbinder, F., Kist, M., and Bereswill, S. 2000. Structural and functional analysis of the riboflavin synthesis genes encoding GTP cyclohydrolase II (ribA), DHBP synthase (ribBA), riboflavin synthase (ribC), and riboflavin deaminase/reductase $(r i b D)$ from Helicobacter pylori strain P1. FEMS (Fed. Eur. Microbiol. Soc.) Microbiol. Lett. 191:191197.

Figurski, D. H., and Helinski, D. R. 1979. Replication of an origin-containing derivative of plasmid RK2 dependent on a plasmid function provided in trans. Proc. Natl. Acad. Sci. U.S.A. 76:1648-1652.

Fleischmann, R. D., Adams, M. D., White, O., Clayton, R. A., Kirkness, E. F., Kerlavage, A. R., Bult, C. J., Tomb, J. F., Dougherty, B. A., Merrick, J. M., McKenney, K., Sutton, G., Fitzhugh, W., Fields, C., Gocayne, J. D., Scott, J., Shirley, R., Liu, L. I., Glodek, A., Kelley, J. M., Weidman, J. F., Phillips, C. A., Spriggs, T., Hedblom, E., Cotton, M. D., Utterback, T. R., Hanna, M. C., Nguyen, D. T., Saudek, D. M., Brandon, R. C., Fine, L. D., Fritchman, J. L., Fuhrmann, J. L., Geoghagen, N. S. M., Gnehm, C. L., McDonald, L. A., Small, K. V., Fraser, C. M., Smith, H. O., and Venter, J. C. 1995. Whole-genome random sequencing and assembly of Haemophilus influenzae Rd. Science 269:496-512.

Fuller, T. E., and Mulks, M. H. 1995. Characterization of Actinobacillus pleuropneumoniae riboflavin biosynthesis genes. J. Bacteriol. 177: 7265-7270.

Honda, S., Okeda, J., Iwanaga, H., Kawakami, S., Taga, A., Suzuki, S., and Imai, K. 2000. Ultramicroanalysis of reducing carbohydrates by capillary electrophoresis with laser-induced fluorescence detection as 7-nitro-2,1,3-benzoxadiazole-tagged $N$-methylglycamine derivatives. Anal. Biochem. 286:99-111.

Lowe, R. H., and Evans, H. J. 1962. Carbon dioxide requirement for growth of legume nodule bacteria. Soil Sci. 94:351-356.

Mavingui, P., Flores, M., Romero, D., Martínez-Romero, E., and Palacios, R. 1997. Generation of Rhizobium strains with improved symbiotic properties by random DNA amplification (RDA). Nature Biotechnol. 15:564-569.

McCormick, D. B. 1989. Two interconnected B vitamins: Riboflavin and pyridoxine. Physiol. Rev. 69:1170-1198.

Meade, H. M., Long, S. R., Ruvkun, G. B., Brown, S. E., and Ausubel, F. M. 1982. Physical and genetic characterization of symbiotic and auxotrophic mutants of Rhizobium meliloti induced by transposon $\operatorname{Tn} 5$ mutagenesis. J. Bacteriol. 149:114-122.

Pella, E. 1990a. Elemental organic analysis: Part 1: Historical developments. Am. Lab. (Shelton) 22(Feb.):116-125.

Pella, E. 1990b. Elemental organic analysis: Part 2: State of the art. Am. Lab. (Shelton) 22(Aug.):28-32.

Perkins, J. B., and Pero, J. G. 1993. Biosynthesis of riboflavin, biotin, folic acid, and cobalamin. Pages 319-334 in: Bacillus subtilis and Other Gram-Positive Bacteria. A. L. Sonenshein, ed. American Society of Microbiology, Washington, DC, U.S.A.

Phillips, D. A., Joseph, C. M., Yang, G. P., Martínez-Romero, E., Sanborn, J. R., and Volpin, H. 1999. Identification of lumichrome as a Sinorhizobium enhancer of alfalfa root respiration and shoot growth. Proc. Natl. Acad. Sci. U.S.A. 96:12275-12280.

Quandt, J., and Hynes, M. F. 1993. Versatile suicide vectors which allow direct selection for gene replacement in Gram-negative bacteria. Gene 127:15-21.

Richter, G., Volk, R., Krieger, C., Lahm, H. W., Röthlisberger, U., and Bacher, A. 1992. Biosynthesis of riboflavin: Cloning, sequencing, and expression of the gene coding for 3,4-dihydroxy-2-butanone 4-phosphate synthase of Escherichia coli. J. Bacteriol. 174:4050-4056.

Richter, G., Ritz, H., Katzenmeier, G., Volk, R., Kohnle, A., Lottspeich, F., Allendorf, D., and Bacher, A. 1993. Biosynthesis of riboflavinCloning, sequencing, mapping, and expression of the gene coding for GTP cyclohydrolase II in Escherichia coli. J. Bacteriol. 175:40454051.

Richter, G., Fischer, M., Krieger, C., Eberhardt, S., Lüttgen, H., Gerstenschläger, I., and Bacher, A. 1997. Biosynthesis of riboflavin: Characterization of the bifunctional deaminase-reductase of Escherichia coli and Bacillus subtilis. J. Bacteriol. 179:2022-2028.

Rovira, A. D., and Harris, J. R. 1961. Plant root excretions in relation to the rhizosphere effect. V. The exudation of B-group vitamins. Plant Soil 14:199-214.

Sambrook, J., Fritsch, E. F., and Maniatis, T. 1989. Molecular Cloning: A Laboratory Manual. Cold Spring Harbor Laboratory Press, Cold Spring Harbor, NY, U.S.A.

Schwinghamer, E. A. 1970. Requirement for riboflavin for effective symbiosis on clover by an auxotrophic mutant strain of Rhizobium trifolii. Aust. J. Biol. Sci. 23:1187-1196.

Simon, R., Priefer, U., and Pühler, A. 1983. A broad host range mobilization system for in vivo genetic engineering: Transposon mutagenesis in gram-negative bacteria. Bio/Technology 1:784-791.

Staskawicz, B., Dahlbeck, D., Keen, N., and Napoli, C. 1987. Molecular characterization of cloned avirulence genes from race 0 and race 1 of Pseudomonas syringae pv. glycinea. J. Bacteriol. 169:5789-5794.

Streit, W. R., and Phillips, D. A. 1996. Recombinant Rhizobium meliloti strains with extra biotin synthesis capability. Appl. Environ. Microbiol. 62:3333-3338.

Streit, W. R., Joseph, C. M., and Phillips, D. A. 1996. Biotin and other water-soluble vitamins are key growth factors for alfalfa root colonization by Rhizobium meliloti 1021. Mol. Plant-Microbe Interact. 9:330338.

Strzelczyk, E., and Rozycki, H. 1985. Production of B-group vitamins by bacteria isolated from soil, rhizosphere, and mycorrhizosphere of pine (Pinus sylvestris L.). Zentralbl. Mikrobiol. 140:293-301.

Taura, T., Ueguchi, C., Shiba, K., and Ito, K. 1992. Insertional disruption of the $n u s B(s s y B)$ gene leads to cold-sensitive growth of Escherichia coli and suppression of the secY24 mutation. Mol. Gen. Genet. 234: 429-432.

Vincent, J. M. 1970. A Manual for the Practical Study of Root-Nodule Bacteria. Vol. 15. Blackwell Scientific Publ., Oxford.

Vincent, J. M. 1977. Rhizobium: General microbiology. Pages 277-366 in: A Treatise on Dinitrogen Fixation. Vol. III. R. W. F. Hardy and W. S. Silver, eds. John Wiley \& Sons, New York.

Wilson, A. C., and Pardee, A. B. 1962. Regulation of flavin synthesis in Escherichia coli. J. Gen. Microbiol. 28:283-303.

Worst, D. J., Gerrits, M. M., Vandenbroucke-Grauls, C. M. J. E., and Kusters, J. G. 1998. Helicobacter pylori ribBA-riboflavin production is involved in iron acquisition. J. Bacteriol. 180:1473-1479.

\section{AUTHOR-RECOMMENDED INTERNET RESOURCES}

Sinorhizobium meliloti genome database: http://sequence.toulouse.inra.fr/ meliloti.html 